Shorter E (1997) A History of Psychiatry: From the Age of the Asylum to the Era of Prozac. John Wiley \& Sons.

Si K, Lindquist S, Kandel ER (2003) A neuronal isoform of the Aplysia CPEB has prion-like properties. Cell 115: 893-904.

Watson JD, Crick FHC (1953) Molecular structure of nucleic acids. A structure for deoxyribose nucleic acid. Nature 171: 737-8.
Watson JD (1968) The Double Helix: A Personal Account of the Discovery of the Structure of DNA. Atheneum.

Whitby LG, Axelrod J, Weil-Malherbe H (1961) The fate of norepinephrine-H3 in animals. Journal of Pharmacology and Experimental Therapy 132: 193-201.

Zaman SH, Zaman R (2001) Long-term potentiation and changes seen in depression. British Journal of Psychiatry 179: 559-60.

\title{
From My Sister and Myself
}

\section{Selected by Femi Oyebode}

It is a curious business certainly. Here are three doctors, three strangers to me and to Nancy [his sister], Drs Brodie, Glover and Walker, and I run to them for help in a matter which covers, includes and exposes the whole of our family life. In a few letters, half an hour's or an hour's conversation, I have to convey to them somehow our characters and history and personal relationships - everything that constitutes our half century of life and beyond. They make up a sort of tribunal to which I have to take my own and the family guilt, the family failure, and they are expected, on what I care or choose to tell them, not only to withdraw my sister from her self-imposed psychosis, but rearrange our shabby and unsuccessful personal relations, in such a way that we shall not destroy ourselves or each other again. What I am saying to these doctors, in effect, is 'Comfort me in my guilt. I have mismanaged my domestic affairs so badly that my sister preferred death to my care, in which she no longer believes. Can you somehow pull her out of it, so that I shall not feel responsible, for the rest of my days? Can you, without knowing any of us, or anything really about any of us, create an atmosphere in which we can all live?' No wonder Dr Brodie seems to me not to understand or give due importance to the dreadful subtleties which seem to me involved. Yet I expect him somehow to launder this half-century-old dirty washing.

\section{IN OTHER} WORDS
R. Ackerley (1896-1967) was literary editor of The Listener from 1935 to 1959 . This extract is from My Sister and Myself: The Diaries of J. R. Ackerley, covering the years 1948-1957. This volume, edited and introduced by F. King, was published by Hutchinson in 1982 Reproduced with kind permission of the publisher.

doi: 10.1192/apt.16.2.85 